\title{
Quality and Safety Assurance According to ISO 22000: 2005 in a Meat Delicatessen Industry of Cyprus
}

\author{
Antonis A. Zorpas*, ${ }^{*}$, Constantina Tzia ${ }^{2}$, Irene Voukali ${ }^{1}$ and Athina Panayiotou ${ }^{3}$ \\ ${ }^{I}$ ENVITECH: Institute of Environmental Technology and Sustainable Development, P.O. Box 34073, 5309, Paralimni, \\ Cyprus \\ ${ }^{2}$ Laboratory of Food Chemistry and Technology, School of Chemical Engineering, National Technical University of \\ Athens, 5 Iroon Polytechniou St, Polytechnioupoli, Zografou, 15780, Athens, Greece \\ ${ }^{3}$ Cyprus Certification Company (CYS - Lead Auditor, Quality Manager) 30, Costa Anaxagora Street, 3rd floor, 2014 \\ Nicosia, Cyprus, P.O. Box 16197, 2086 Nicosia, Cyprus
}

\begin{abstract}
Quality and safety are very important for the meat delicatessen industries. In Cyprus, food industries have started to apply safety programs the past few years in a preliminary way in order to comply with the current food safety directives or regulations. The verification activities in food industries encompass sampling for monitoring GMPs-GHPs and CCPs and determination of microbiological variables, review of records, flow diagrams and HACCP plan. The present paper describes the application of the above according to the standard ISO 22000:2005 in a meat delicatessen industry in Cyprus.
\end{abstract}

Keywords: Meat delicatessen, meat hygiene, GMPs-GHPs, HACCP, ISO 22000.

\section{INTRODUCTION}

Food safety has been the topic of some recent policy changes, increased awareness among the public, and various incidents. These developments indicate that there is a need for a system that can identify food safety hazards in an early stage so that these hazards can be tackled in time, before developing into real risks. With regard to food safety hazards that are known as such, measures can be taken towards the prevention and mitigation of these hazards based on their characteristics, behavior and point of entry into the food chain. For example, good practices for agriculture and manufacturing (GAPs and GMPs-GHPs), as well as the Hazard Analysis Critical Control Points (HACCP) approach to assess risks and control them, have a commonplace in many jurisdictions. However, it can be envisioned that for a number of risks, such measures may not be applicable given that these risks are yet unknown or unanticipated.

Food hygiene is defined by Codex Alimentarius as "all conditions and measures necessary to ensure the safety and suitability of food in all steps of food chain" (Codex Alimentarius, 1999, 2002) [1,2]. HACCP system is compulsory in EU member states for safety assurance based on hazard analysis, while prerequisite hygiene programs (GHPs: Good Hygiene Practices, GMPs: Good Manufacturing Practices) are necessary to support the system [3]. According to the HACCP principles, in each step of the food process, all possible hazards (physical, chemical, microbiological) are identified, their importance is evaluated and all the preventive

*Address correspondence to this author at the ENVITECH: Institute of Environmental Technology and Sustainable Development, P.O. Box 34073, 5309, Paralimni, Cyprus; Tel: +357-23743440; Fax: +357-23743441; E-mail: antoniszorpas@envitech.org measures for their control are described (principle 1). The Critical Control Points (CCPs) should be identified by risk assessment according to ISO 22000:2005 [4] where monitoring is critical for controlling the safety of the product (principle 2). For each identified CCP, critical limits for preventive measures (principle 3 ) and monitoring systems (principle 4) are established. When monitoring shows that a critical limit has not been met, corrective actions must be taken (principle 5). Finally, procedures to verify that the system is working properly (principle 6) and effective records to document the HACCP system are established (principle 7), $[3,5]$.

Methods to conduct a hazard analysis [6] and establish critical control points using risk assessment and food borne outbreak evaluations [7-9] have recently been supported by elaboration of the risk profiling approach. HACCP is a highly specialized system for food safety that is needed for carrying out an analytical study about microbiological, chemical and physical hazards. Hazard analysis contains the identifications of potential hazards throughout the food process and the identification of critical steps (CCPs) that must be controlled to assure food safety $[3,5]$. HACCP based programs were implemented in the 1990's to enhance food safety and quality. Preventive measures in terms of adequate process controls accompanied by periodic verification and corrective actions were considered more effective than inspecting defects out of each final product [10].

Quality and safety are important for the meat delicatessen industries. Quality assurance of the whole process is significant for the consumer acceptability, while safety assurance is obligatory for protection of public health. Quality is required in order for the product to meet the customers' specifications and may be assured by the application of quality management systems, such as ISO 9001. As far as food safety is 


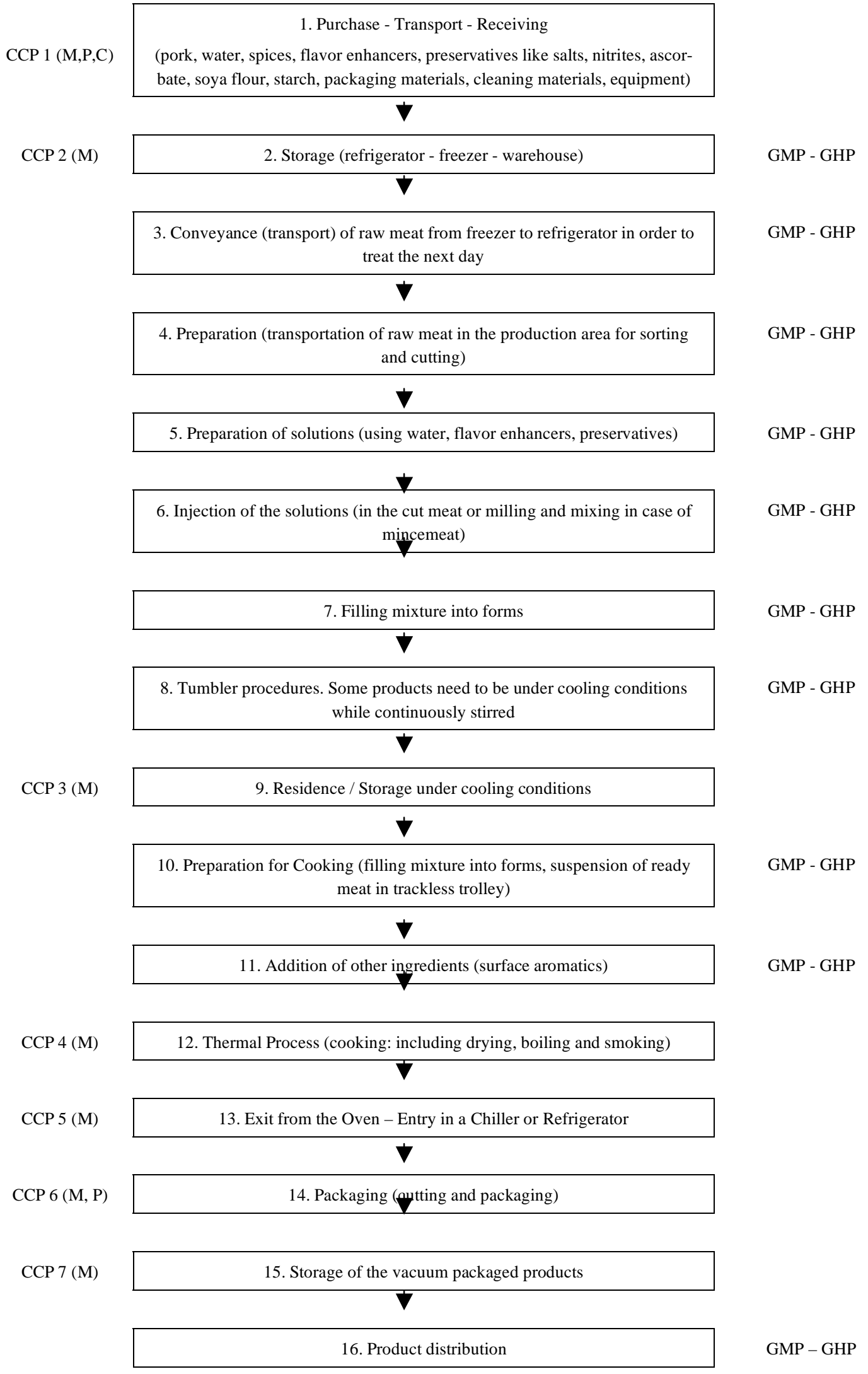

Fig. (1). General flow chart for the production of meat delicatessen (M: Microbiological, P: Physical, C: Chemical hazard). 
Table 1. The Possibility of the Appearance of Negative Impact on Public Health (SEVERITY-S)

\begin{tabular}{|c|l|}
\hline Grade & \multicolumn{1}{|c|}{ Definition } \\
\hline \hline $\mathbf{0}$ & No damage or human ill. No legal requirement. \\
\hline $\mathbf{2}$ & $\begin{array}{l}\text { Low concentration of microbiological activities in the food which is under the limits. No serious illness of the consumer. No legal } \\
\text { requirement. All the parameters, microbiological and chemical, are under the limits of all the directives or legislations. Physical } \\
\text { hazards can be controlled. }\end{array}$ \\
\hline $\mathbf{3}$ & $\begin{array}{l}\text { The product can be characterized as degrading (High concentration of microorganisms and the product has low quality). If the } \\
\text { product proceeds to the consumer it may affect selected populations, such as the elderly or infants. Mild occurrence of food poison- } \\
\text { ing. The product should be removed from the market. May have a legal claim. }\end{array}$ \\
\hline $\begin{array}{l}\text { The product is not acceptable. All the parameters are over the limits. If the product is consumed, the consumer may be in hazard. } \\
\text { Occurrence of a serious food poisoning. Definite legal claim. The product must be immediately removed from the market. }\end{array}$ \\
\hline
\end{tabular}

concerned, food legislation of European Union, recognizing the significance of safety for human health, has established the application of Council Directive 93/43/EEC \& Regulation (EC) No 852/2004 [11, 12] in which the basic hygiene and HACCP requirements are defined (directive 93/43 is no longer in force, because it has been repealed by Regulation EC 852/2004). In Cyprus, food industries have started to apply safety assurance programs during the past few years in a preliminary way in order to comply with the current food safety directives or regulations [11-15]. Implementation of HACCP system is a fundamental approach to ensure the safety of food supply, providing a systematic procedure for the identification, evaluation and control of hazards in each operation [16]. Small business may lack in house knowledge and resources required for the correct implementation of HACCP. Before implementing a HACCP system, a food business should already have in place various practices that may be collectively termed "prerequisite programs" (PRPs) (e.g. raw materials' specifications, staff training, hygienically designed facilities and good hygiene practice - GHP) [17-20].

Risk profiling is one activity in preliminary risk management, which has been recently defined as a description of a food safety problem and its context developed for the purpose of identifying those elements of a hazard or risk that are relevant to risk management decisions (Codex Alimentarius Commission, 2002) [2]. Risk profiling involves the systematic collection of information needed to make a decision on what will be done next and which resources should be allocated to more detailed scientific assessment. The risk profiling process typically provides information on: the hazard, exposure to the hazard, adverse health effects, public health surveillance information, control measures and other information relevant to risk management decision-making.

In Cyprus there are about 20 meat delicatessen industries which treat pork, beef, turkey and chicken in order to produce bacon and different kinds of ham, salami, sausages and mortadella. The most common ingredients, in addition to meat, are: water, spices, flavor enhancers, preservatives (like salts, nitrites) or antioxidants (ascorbate), soya flour and starch. Coriander, a local spice with special aroma and taste, is used in many traditional products and is very pleasing to the Cyprian consumers. For proper meat processing, relative or special equipment like cutter machines, tumblers, injections, guillotine, packaging machines, coolers, ovens, smok- ers, chillers, cutting machines etc. are used in these industries.

The verification activities in food industries encompass sampling for monitoring CCPs and determination of microbiological variables, review of records, flow diagrams and HACCP plan. However, regarding the implementation of such a safety assurance system, hygiene programs like GHPs-GMPs are also required.

\section{MATERIALS AND METHODS}

Bacon, lountza, hiromeri, ham and sausages are some of the meat delicatessens produced in Cyprus. Lountza (smoked fillet of pork) and hiromeri are typical meat delicatessen of Cyprus and very common to the culture of Cyprus. Hiromeri resembles the Italian Prosciutto. Pork meat is the main raw material for the production of the above products, while water, spices, flavor enhancers, preservatives (like salts, nitrites), ascorbate, soya flour, starch are necessary ingredients as well.

Bacon, lountza, hiromeri, ham and sausages are produced following a general flow diagram (Fig. 1). This represents the typical production of meat delicatessen based on both the bibliography [21] and the suggestions of the industry's expertise. The processing steps differentiate depending on the product.

In each step of the process, the first two principles of HACCP are developed. Thus, all possible hazards (physical, chemical, microbiological) are identified, the preventive measures are described and CCPs are identified by risk assessment according to ISO 22000:2005 [4] (Tables 1, 2, 3). Especially, risk assessment of risk levels taking into account both the possibility of appearance and the severity of the hazard is used. Following, as the remaining principles require, for each identified CCP, critical limits for preventive

Table 2. The Possibility of the Appearance of the Specific Hazard (PROBABILITY -P)

\begin{tabular}{|c|l|}
\hline Grade & \multicolumn{1}{|c|}{ Definition } \\
\hline \hline $\mathbf{0}$ & Maybe or Low possibility of appearance \\
\hline $\mathbf{1}$ & Possible to happen \\
\hline $\mathbf{2}$ & Very Possible to happen \\
\hline
\end{tabular}


Table 3. Risk Level Estimator [RISK = SEVERITY + PROBABILITY]

\begin{tabular}{|c|c|c|c|c|}
\hline & \multicolumn{3}{|c|}{ Severity } \\
\hline Probability & $\mathbf{0}$ & $\mathbf{1}$ & $\mathbf{2}$ & $\mathbf{3}$ \\
\hline \hline 0 & 0 & 1 & 2 & 3 \\
\hline 1 & 1 & 2 & 4 & 5 \\
\hline 2 & 2 & 3 & 5 \\
\hline
\end{tabular}

measures and monitoring systems are proposed, as well as corrective actions. Based on these data, procedures to verify and effective records to document the HACCP system can be established. Also, prerequisite measures related to GMPs GHPs in each production step are described.

\section{RESULTS AND DISCUSSION}

For the meat products examined, processes are applied according to Fig. (1). Raw materials receipted in the industry are stored, pork meat under refrigeration (up to 6 days) or in the freezer (up to 6 weeks) and other materials in the warehouse. The required amount of meat, one day before processing, is transported from the freezer to the refrigerator. The rest of the materials, in the required amounts, are transported to the production area. The preparation of meat involves sorting and cutting, as well as the addition of necessary substances in solution (flavor enhancers, preservatives). The solution is injected into the minced meat and the mixture is filled into forms. Following, the mixture is processed in the tumbler and then, either cooled or intended for cooking and the final products are packaged, stored and distributed. Alternative steps which are applied for the production of particular products are referred below.

For the production of streaky and back bacon, all the steps (Fig. 1) except step 7 are followed. Step 11 takes place in case an aroma of coriander (typical

\section{Table 4. Risk Level Definitions}

\begin{tabular}{|c|c|c|}
\hline Risk Level & Definitions & Required control action \\
\hline $\mathbf{0}$ & Uncreated & Very low hazard. Typical preventing actions. \\
\hline 1 & Very Low & $\begin{array}{l}\text { The hazard is accepted by the company and is under the limits of legislation. The acknowledged hazard presents problems } \\
\text { only in selected populations (like: diabetics or persons having cardiovascular problems). }\end{array}$ \\
\hline 2 & Low & $\begin{array}{l}\text { Hazard that requires more check and control (optical check is accepted). The acknowledged hazard presents problems only } \\
\text { in selected populations (like: diabetics or persons having cardiovascular problems). Perhaps the HACCP plan needs } \\
\text { changes. If the corrective actions are repeated more than } 30 \% \text { in the same point or procedure in the total corrective actions } \\
\text { in the same year then must be a Critical Point. Nevertheless, the specific hazard does not present any public health hazard. } \\
\text { All the parameters are under the limits and product is safe. }\end{array}$ \\
\hline 3 & Fair & $\begin{array}{l}\text { Hazard that is not accepted. However, the miss control of the hazard does not present any hazards to the public health. It } \\
\text { presents problems only in selected populations (like: diabetics or persons having cardiovascular problems). Also, the } \\
\text { product can be characterized as degrading. If the corrective actions are repeated more than } 10 \% \text { in the same point or pro- } \\
\text { cedure in the total corrective actions in the same year then it must be a Critical Point. The HACCP plan must be re- } \\
\text { checked. The product needs laboratory checks and then to proceed with corrective actions in order that the procedures } \\
\text { return within safe limits. There is a possibility of food poisoning (with transiently symptoms). If the product is in the mar- } \\
\text { ket it must be traced back. }\end{array}$ \\
\hline 4 & High & $\begin{array}{l}\text { This is a CCP. The hazard is not accepted and if it is out of limits problems can be caused to the consumer. The hazard } \\
\text { affects all consumer populations. The product can be characterized as degrading to hazardous for the human health. If the } \\
\text { corrective actions are repeated more than } 5 \% \text { in the same point or procedure in the total corrective actions in the same } \\
\text { year then it must be a Critical Point. The HACCP plan must be re-checked. The product needs laboratory checks and then } \\
\text { to proceed with corrective actions in order that the procedures return within safe limits. The HACCP Team must be noti- } \\
\text { fied and then all the procedures must be stopped. The HACCP team must take corrective actions while the product must } \\
\text { be removed from the market. }\end{array}$ \\
\hline 5 & Very High & $\begin{array}{l}\text { CCP. The entire recognized hazards are not acceptable. The product is characterized as unacceptable and very hazardous if } \\
\text { it is out of limits. The product can be characterized as degrading to hazardous for the human health. If the corrective ac- } \\
\text { tions are repeated more than } 5 \% \text { in the same point or procedure in the total corrective actions in the same year then it must } \\
\text { be a Critical Point. The HACCP plan must be re-checked. The product needs laboratory checks and then to proceed with } \\
\text { corrective actions in order that the procedures return within safe limits. The HACCP Team must be notified and then all } \\
\text { the procedures must be stopped. The HACCP team must take corrective actions while the product must be removed im- } \\
\text { mediately from the market. }\end{array}$ \\
\hline
\end{tabular}


aromatic herb from Cyprus) should be obtained for special customer demands.

$>\quad$ Lountza (or smoked fillet of pork). This meat delicatessen of Cyprus is prepared from fillet of pork with no covering fat, using all the steps described above (Fig. 1) except step 7. Similarly, step 11 takes place, if an aroma of coriander is demanded.

Hiromeri is a traditional meat delicatessen of Cyprus which is prepared by following steps 1-4 and 14-16 (Fig. 1). Mixing of salts with meat and storage in the refrigerator (step 9) is conducted by hands. After a period of 2-5 weeks, the meat is transferred to a wine bath for more than a month in the refrigerator (step 9). Then it remains at dry air under controlled conditions and is finished by drying and smoking (step 13).

Leg ham - smoked ham is prepared (Fig. 1) by following steps 1-5. In step 6 the meat is mixed in a cutter making a mush sample. Steps 8 and 11 are not applied. The thermal process (step 12) includes boiling and smoking.

$>\quad$ Sausage (Cyprian Sausage) is prepared using steps 1-5. Steps 8 and 11 are not applied (Fig. 1). The meat is cut as mincemeat in step 6 . The mixture is filled in natural bowels, remains at dry air under controlled conditions and follows the steps 12-16.

The identification of CCPs and the required actions for their control are crucial for the appropriate HACCP development. However, nowadays, risk assessment and quantification of hazards are recommended focusing on the consumer's health, while a higher safety level is proposed. In order to identify CCPs, the methods used are presented in Tables 1-4. Table 1 presents the possibility of the appearance of negative impact on public health (SEVERITY-S) using grades $0-3$. Table 2 shows the possibility of the appearance of the specific hazard (PROBABILITY-P) using grades 0-2. Table 3 presents the Risk Level, where Risk Level $(\mathrm{R})=\mathrm{S}+$ $\mathrm{P}$, using scale $0-2$ for probability and scale $0-3$ for severity. Table $\mathbf{4}$ shows the Definitions of Risk Level using levels 0-5. Table 5 presents the risk assessment results of the flow chart (Fig. 1).

According to ISO 22000:2005, all food safety hazards that are reasonably expected to occur in relation to the type of product, type of process and actual processing facilities should be identified and recorded. The identification is based:

$\sqrt{ } \quad$ On experience.

$\checkmark$ On external information from, to the extent possible, epidemiological and other historical data.

$\checkmark \quad$ On the preliminary information data collected according to the food safety team, the product's characteristics (microbiological, chemical, physical), methods of production, storage conditions and shelf life, preparation and/or handling before using processing, packaging and delivery methods.

Hazard assessment shall be conducted to determine each food safety hazard identified whether its elimination or reduction to acceptable levels is essential to the production of a safe food and whether its control is needed to enable the de- fined acceptable levels to be met. Each food safety hazard shall be evaluated according to the possible severity of adverse health effects and the likelihood of their occurrence.

\section{CCPs}

The results of the analysis on the quality and safety hazards of the meat delicatessen industry are presented in Table 6. The Table should be used complementary to the following results. Incoming materials, especially raw meat used in large quantities, is a sensitive food as it may support the growth of microorganisms. For the above mentioned reason, raw materials' delivery is characterized as a Critical Control Point (CCP 1) and should be examined in each receipt. Certified suppliers and rigorous criteria for raw materials, additives with low microbial counts and absence of pathogens could greatly contribute to the hygienic quality and safety of the final product. Food handling errors, inadequate storage practices and improper holding temperatures may also occur [22]. The storage temperature consists of an important Critical Control Point (CCP 2, 3, 7). Thus, during storage at chilling conditions the temperature has to be maintained at $4^{\circ} \mathrm{C}$ or less in order to ensure the microbiological safety of cooked products.

During the thermal process (step 12 from Fig. 1) the core temperature of a product consists of a Critical Control Point (CCP 4). Cooked products should be heated until they reach an internal temperature well over $72^{\circ} \mathrm{C}$. In order to avoid the growth of any thermo-tolerant bacteria or spores potentially present, it is essential to cool products rapidly after processing and to prevent storage at high ambient temperatures. Reducing the temperature from 72 to $10^{\circ} \mathrm{C}$ has to be attained in less than $2 \mathrm{hrs}$ and consequently, the time needed to cool down the cooked product is characterized as a Critical Control Point (CCP 5). Major sources of contamination are the slicing and packaging room (CCP 6). Moreover, the staff's personal hygiene has to be the appropriate.

\section{GMPs - GHPs}

Table 7 presents the GMPs and GHPs required in all production steps in order to avoid contamination. In addition to the most significant factors and the relative required controls involved with CCPs, all the other factors in those steps must be controlled in order to assure quality and safety. Such controls usually are prerequisite measures which are grouped and organized by means of hygiene practices.

The processes of Meat Distribution Industry (meat delicatessen) include steps that are not under the industry's responsibilities. The animals' farm, animal feeds, slaughterhouse procedures, transportation of raw meat can not be easily controlled by the industry. The quality and safety of the meat delicatessen are related to the above.

All the requirements related to hygienic practices during the industry's operations, either referred to equipment maintenance or to cleaning / disinfection procedures of equipment or to the control of foreign matters, must be included in the prerequisite programs (PRPs).

Critical factors of hygiene and safety assurance during the production of all meat delicatessen (bacon, lountza, hiromeri, ham, sausages) were the temperature in the processing lines, which must be held below $12^{\circ} \mathrm{C}$ and hygienic practices, not only by the personnel but also by the sanitation of 
Table 5. Risk Assessment Result (M: Microbiological, C: Chemical, P: Physical Hazardous)

\begin{tabular}{|c|c|c|c|c|c|}
\hline Step of the flow chat (Fig.1) & Hazard & $\begin{array}{l}\text { Severity } \\
\text { (S) }\end{array}$ & $\begin{array}{l}\text { Probability } \\
\quad \text { (P) }\end{array}$ & $\begin{array}{c}\text { Risk } \\
(\mathbf{R}=\mathbf{S}+\mathbf{P})\end{array}$ & $\begin{array}{l}\text { Category } \\
\text { CCP/GMP }\end{array}$ \\
\hline \multirow{3}{*}{ Purchase - Transport - Receiving } & M & 3 & 2 & 5 & $\mathrm{CCP} 1$ \\
\hline & $\mathrm{C}$ & 3 & 2 & 5 & $\mathrm{CCP} 1$ \\
\hline & $\mathrm{P}$ & 3 & 2 & 5 & $\mathrm{CCP} 1$ \\
\hline \multirow{3}{*}{ Storage } & M & 3 & 2 & 5 & $\mathrm{CCP} 2$ \\
\hline & $\mathrm{C}$ & 2 & 1 & 3 & GMP \\
\hline & $\mathrm{P}$ & 2 & 1 & 3 & GMP \\
\hline \multirow{3}{*}{$\begin{array}{l}\text { Conveyance (transport) of raw meat from freezer } \\
\text { to refrigerator in order to treat the next day }\end{array}$} & M & 2 & 1 & 3 & GMP \\
\hline & $\mathrm{C}$ & 2 & 1 & 3 & GMP \\
\hline & $\mathrm{P}$ & 2 & 1 & 3 & GMP \\
\hline \multirow{3}{*}{$\begin{array}{l}\text { Preparation (Transportation of raw meat in the } \\
\text { production area for sorting and cutting) }\end{array}$} & M & 1 & 2 & 3 & GMP \\
\hline & $\mathrm{C}$ & 1 & 1 & 2 & GMP \\
\hline & $\mathrm{P}$ & 1 & 1 & 2 & GMP \\
\hline \multirow{3}{*}{$\begin{array}{l}\text { Preparation of solutions (using water, flavor en- } \\
\text { hancers, preservatives) }\end{array}$} & M & 1 & 1 & 2 & GMP \\
\hline & $\mathrm{C}$ & 2 & 1 & 3 & GMP \\
\hline & $\mathrm{P}$ & 1 & 1 & 2 & GMP \\
\hline \multirow{3}{*}{$\begin{array}{l}\text { Injection of solutions (in the cut meat or milling } \\
\text { and mixing in case of mincemeat) }\end{array}$} & M & 1 & 1 & 2 & GMP \\
\hline & $\mathrm{C}$ & 2 & 1 & 3 & GMP \\
\hline & $\mathrm{P}$ & 2 & 1 & 3 & GMP \\
\hline \multirow{3}{*}{ Filling mixture into forms } & M & 1 & 1 & 2 & GMP \\
\hline & $\mathrm{C}$ & 1 & 1 & 2 & GMP \\
\hline & $P$ & 1 & 1 & 2 & GMP \\
\hline \multirow{3}{*}{$\begin{array}{l}\text { Tumbler procedures. Some products need to be } \\
\text { under cooling conditions while continuously } \\
\text { stirred }\end{array}$} & M & 1 & 2 & 3 & GMP \\
\hline & $\mathrm{C}$ & 1 & 1 & 2 & GMP \\
\hline & $P$ & 1 & 1 & 2 & GMP \\
\hline \multirow{3}{*}{ Residence / Storage under cooling conditions } & M & 2 & 2 & 4 & $\mathrm{CCP} 3$ \\
\hline & $\mathrm{C}$ & 1 & 2 & 3 & GMP \\
\hline & $\mathrm{P}$ & 1 & 2 & 3 & GMP \\
\hline \multirow{3}{*}{$\begin{array}{l}\text { Preparation for Cooking (Filling mixture into } \\
\text { forms, suspension of ready meat in trackless } \\
\text { trolley) }\end{array}$} & M & 1 & 1 & 2 & GMP \\
\hline & $\mathrm{C}$ & 1 & 1 & 2 & GMP \\
\hline & $\mathrm{P}$ & 1 & 1 & 2 & GMP \\
\hline \multirow{3}{*}{ Addition of other ingredients (surface aromatics) } & M & 1 & 2 & 3 & GMP \\
\hline & $\mathrm{C}$ & 1 & 2 & 3 & GMP \\
\hline & $\mathrm{P}$ & 1 & 1 & 2 & GMP \\
\hline \multirow{3}{*}{$\begin{array}{l}\text { Thermal Process (Cooking: including drying, } \\
\text { boiling and smoking) }\end{array}$} & M & 3 & 2 & 5 & $\mathrm{CCP} 4$ \\
\hline & $\mathrm{C}$ & 1 & 2 & 3 & GMP \\
\hline & $\mathrm{P}$ & 1 & 2 & 3 & GMP \\
\hline \multirow{3}{*}{$\begin{array}{c}\text { Exit from the Oven - Entry in a Chiller or Refrig- } \\
\text { erator }\end{array}$} & M & 2 & 2 & 4 & $\mathrm{CCP} 5$ \\
\hline & $\mathrm{C}$ & 1 & 2 & 3 & GMP \\
\hline & $\mathrm{P}$ & 1 & 1 & 2 & GMP \\
\hline \multirow{3}{*}{ Packaging (cutting and packaging) } & M & 2 & 2 & 4 & CCP 6 \\
\hline & $\mathrm{C}$ & 1 & 2 & 3 & GMP \\
\hline & $\mathrm{P}$ & 2 & 2 & 4 & $\mathrm{CCP} 6$ \\
\hline \multirow{3}{*}{ Storage of the vacuum packaged products } & M & 2 & 2 & 4 & $\mathrm{CCP} 7$ \\
\hline & $\mathrm{C}$ & 1 & 1 & 2 & GMP \\
\hline & $\mathrm{P}$ & 1 & 1 & 2 & GMP \\
\hline \multirow{3}{*}{ Product distribution } & M & 2 & 1 & 3 & GMP \\
\hline & $\mathrm{C}$ & 1 & 1 & 2 & GMP \\
\hline & $\mathrm{P}$ & 1 & 1 & 2 & GMP \\
\hline
\end{tabular}


Table 6. HACCP Sheet - Analysis for the Safety Hazards, CCPs and their Control (M: Microbiological, C: Chemical, P: Physical Hazards)

\begin{tabular}{|c|c|c|c|c|}
\hline $\begin{array}{l}\text { Step of the flow chat } \\
\text { (Fig.1) }\end{array}$ & Hazards & $\begin{array}{l}\text { Critical Factor/Limits/ } \\
\text { Controls }\end{array}$ & $\begin{array}{l}\text { Parameters to be moni- } \\
\text { tored for a particular CCP }\end{array}$ & Preventive measure \\
\hline $\begin{array}{l}\text { Purchase - Transport } \\
\text { - Receiving } \\
\text { (CCP } 1 \mathrm{M}, \mathrm{C}, \mathrm{P}) \\
\text { Pork }\end{array}$ & $\begin{array}{l}\text { Microbiological } \\
\text { Salmonella spp, Campy- } \\
\text { lobacter, Staphylococcus } \\
\text { aureus, Clostridium perfrin- } \\
\text { gens, Clostridium botu- } \\
\text { linum, Escherichia coli, } \\
\text { Yersinia enterocolotica, } \\
\text { Listeria monocytogenes, } E \text {. } \\
\text { coli, Faecal coliforms, Coli- } \\
\text { forms or Enterobacteria } \\
\text { Chemical } \\
\text { Antibiotics, Mycotoxins } \\
\text { (barely), hormone auxin } \\
\text { Physical } \\
\text { Absence of impurities }\end{array}$ & $\begin{array}{l}\text { TVC: } 10^{4} \text { or } 10^{5}-10^{6} \\
\text { E. coli and Faecal coliforms: } 50- \\
1 \times 10^{2} \\
\text { Coliforms or Enterobacteria: } \\
1 \times 10^{2} \text { or } 1 \times 10^{3} \\
\text { Salmonella spp: } 0 / 25 \mathrm{~g} \text { or } 50 \mathrm{~g} \\
\text { Staphylococcus aureus: } 1 \times 10^{2} \text { - } \\
1 \times 10^{3} \\
\text { Clostridium perfringens: } 10-30 \\
\text { Yield and molds: } 5 \times 10^{3} \\
\text { Chemical characteristics } \\
\text { Shelf life: moisture } 85-90 \%, \mathrm{pH} \\
5-5.5\end{array}$ & $\begin{array}{l}\text { Temperature } \\
\text { Organoleptic characteristics } \\
\text { (color, smell, appearance) } \\
\text { Microbiological analysis } \\
\text { Chemical analysis: } \\
\text { moisture, pH }\end{array}$ & $\begin{array}{l}\text { Supplier control and audits } \\
\text { Transport control and } \\
\text { checks (hygiene checks) } \\
\text { Temperature control } \\
\text { Control of organoleptic } \\
\text { characteristics (color, smell, } \\
\text { appearance) } \\
\text { Reject improper meat } \\
\text { Health certificates }\end{array}$ \\
\hline $\begin{array}{l}\text { Purchase - Transport } \\
\text { - Receiving } \\
\text { (CCP 1 M,C,P) } \\
\text { Starch }\end{array}$ & $\begin{array}{l}\text { Microbiological } \\
\text { Salmonella spp, Bacillus } \\
\text { cereus } \\
\underline{\text { Chemical }} \\
\text { Mycotoxins, pesticides } \\
\underline{\text { Physical }} \\
\text { Absence of impurities }\end{array}$ & $\begin{array}{l}\text { Product specifications } \\
\text { TVC: } 10^{6} \\
\text { Salmonella spp: } 0 / 25 \mathrm{~g} \\
\text { Bacillus cereus }<20 \\
\text { Shelf life }\end{array}$ & $\begin{array}{l}\text { Microbiological analysis } \\
\text { Temperature } \\
\text { Organoleptic characteris- } \\
\text { tics (color, smell, appear- } \\
\text { ance) } \\
\text { Chemical analysis }\end{array}$ & $\begin{array}{l}\text { Supplier control and audits } \\
\text { Transport control and } \\
\text { checks (hygiene checks) } \\
\text { Reject improper starch } \\
\text { Health certificates } \\
\text { Mycotoxins and pesticides } \\
\text { analysis }\end{array}$ \\
\hline $\begin{array}{l}\text { Purchase - Transport } \\
\text { - Receiving } \\
\text { (CCP 1 M,C,P) } \\
\text { Spices }\end{array}$ & $\begin{array}{l}\text { Microbiological } \\
\text { Salmonella spp, Bacillus } \\
\text { cereus, } \\
\text { Clostridium botulinum, } \\
\text { Staphylococcus aureus, E. } \\
\text { coli, Faecal coliforms, Clos- } \\
\text { tridium perfringens, Coli- } \\
\text { forms or Enterobacteria } \\
\text { Chemical } \\
\text { Toxins (aflatoxins) } \\
\underline{\text { Physical }} \\
\text { Absence of impurities }\end{array}$ & $\begin{array}{l}\text { Product specifications } \\
\text { Shelf life } \\
\text { TVC: } 5 \times 10^{5} \\
\text { Salmonella spp: } 0 / 25 \mathrm{~g} \\
\text { E. coli: negative }-2 \times 10^{2} \\
\text { Staphylococcus aureus: } 1 \times 10^{2} \\
\text { Clostridium perfringens: } 1 \times 10^{2} \\
\text { Coliforms or Enterobacteria: } \\
5 \times 10^{2} \\
\text { Toxins }\end{array}$ & $\begin{array}{l}\text { Temperature } \\
\text { Organoleptic characteris- } \\
\text { tics (color, smell, appear- } \\
\text { ance) } \\
\text { Microbiological analysis } \\
\text { Chemical analysis }\end{array}$ & $\begin{array}{l}\text { Supplier control and audits } \\
\text { Transport control and } \\
\text { checks (hygiene checks) } \\
\text { Reject improper spices } \\
\text { Health certificates } \\
\text { Free of aflatoxins }\end{array}$ \\
\hline $\begin{array}{l}\text { Purchase - Transport } \\
\text { - Receiving } \\
\text { (CCP 1 M,C) } \\
\text { Water }\end{array}$ & $\begin{array}{l}\text { Microbiological } \\
\text { TVC, Staphylococcus } \\
\text { aureus, E. coli, Faecal coli- } \\
\text { forms, Coliforms, Entero- } \\
\text { bacteria } \\
\text { Chemical } \\
\mathrm{Metals}^{\mathrm{N}} \mathrm{NH}_{4}, \mathrm{NO}_{3}, \mathrm{NO}_{2}, \\
\mathrm{PO}_{4}, \mathrm{~B}, \mathrm{Cl}, \mathrm{Na}, \mathrm{Ka}, \mathrm{Ca}, \mathrm{Mg}\end{array}$ & $\begin{array}{l}\text { Council Directive 98/83/EC, } \\
\text { Directive 2000/60/EC }\end{array}$ & $\begin{array}{l}\text { Microbiological analysis } \\
\text { Chemical analysis }\end{array}$ & Microbiological analysis \\
\hline $\begin{array}{l}\text { Purchase - Transport } \\
\text { - Receiving } \\
\text { (CCP 1 M,C) } \\
\text { Packaging Materials }\end{array}$ & $\begin{array}{l}\text { Microbiological } \\
\text { Only from cross- } \\
\text { contamination (TVC, } \\
\text { Staphylococcus aureus, E. } \\
\text { coli, etc) } \\
\underline{\text { Chemical }} \\
\text { Residual substances }\end{array}$ & $\begin{array}{l}\text { Product specifications } \\
\text { Food grade certifications } \\
\text { Migration test }\end{array}$ & Migration test & $\begin{array}{l}\text { Supplier control and audits } \\
\text { Certificates for food grade } \\
\text { Hygienic control }\end{array}$ \\
\hline
\end{tabular}


(Table 6). Contd.....

\begin{tabular}{|c|c|c|c|c|}
\hline $\begin{array}{l}\text { Step of the flow chat } \\
\text { (Fig.1) }\end{array}$ & Hazards & $\begin{array}{l}\text { Critical Factor/Limits/ } \\
\text { Controls }\end{array}$ & $\begin{array}{l}\text { Parameters to be moni- } \\
\text { tored for a particular CCP }\end{array}$ & Preventive measure \\
\hline $\begin{array}{l}\text { Storage } \\
\text { CCP (M) } \\
\text { Meat - Pork }\end{array}$ & $\begin{array}{l}\text { Microbiological } \\
\text { Increase of pathogens ap- } \\
\text { pearing in meat } \\
\text { Formation of toxins from } \\
\text { microorganisms } \\
\text { Cross-contamination from } \\
\text { staff } \\
\text { Chemical } \\
\text { Mycotoxins } \\
\text { Physical } \\
\text { Absence of impurities (like } \\
\text { pieces of packaging materi- } \\
\text { als) }\end{array}$ & $\begin{array}{l}\text { Temperature control / time } \\
2-4 \text { or } 6 \text { days for refrigerated } \\
\text { and } 6 \text { weeks for frozen } \\
0-3^{\circ} \mathrm{C} \text { or }<-18^{\circ} \mathrm{C} \\
\text { Calibration of the storage areas } \\
\text { Contractors specification of the } \\
\text { storage areas } \\
\text { Refrigerator and refrigerator } \\
\text { insulation } \\
\text { FIFO } \\
\text { Supplier control } \\
\text { Implementation of standard } \\
\text { cleaning programs } \\
\text { Implementation of maintenance } \\
\text { programs }\end{array}$ & $\begin{array}{l}\text { Temperature } \\
\text { Microbiological analysis } \\
\text { Chemical analysis }\end{array}$ & $\begin{array}{l}\text { Continuous temperature } \\
\text { control every } 15 \text { minutes } \\
\text { Preventive maintenance } \\
\text { program } \\
\text { Calibration } \\
\text { Control and check of resis- } \\
\text { tance time of the meat } \\
\text { Internal audits } \\
\text { Implementation of standard } \\
\text { cleaning programs } \\
\text { Plastic boxes must be clear } \\
\text { and clean } \\
\text { Continuous checks to iden- } \\
\text { tify improper meat }\end{array}$ \\
\hline $\begin{array}{l}\text { Storage areas } \\
\text { Additives } \\
\text { GMP - GHP }\end{array}$ & $\begin{array}{l}\text { Microbiological } \\
\text { Increase of pathogens } \\
\text { Formation of toxins from } \\
\text { microorganisms } \\
\text { Cross-contamination from } \\
\text { staff } \\
\underline{\text { Chemical }} \\
\text { Mycotoxins, other additives } \\
\underline{\text { Physical }} \\
\text { Absence of impurities }\end{array}$ & $\begin{array}{l}\text { Temperature control / time } \\
2-4 \text { or } 6 \text { days for refrigerated } \\
\text { and } 6 \text { weeks for frozen } \\
0-3^{\circ} \mathrm{C} \text { or }<-18^{\circ} \mathrm{C} \text {, storage } \\
12-18^{\circ} \mathrm{C} \\
\text { Calibration of the storage areas } \\
\text { Contractors specification of the } \\
\text { storage areas } \\
\text { Refrigerator and refrigerator } \\
\text { insulation } \\
\text { FIFO } \\
\text { Supplier control } \\
\text { Implementation of standard } \\
\text { cleaning programs }\end{array}$ & & $\begin{array}{l}\text { Continuous temperature } \\
\text { control every } 15 \text { minutes } \\
\text { Checks for the shelf life of } \\
\text { the products (expiration } \\
\text { dates) } \\
\text { Daily internal audits } \\
\text { All the additives must be in } \\
\text { closed boxes if they are } \\
\text { open } \\
\text { Implementation and im- } \\
\text { provement of cleaning pro- } \\
\text { grams }\end{array}$ \\
\hline $\begin{array}{l}\text { Conveyance (trans- } \\
\text { port) of raw meat } \\
\text { from freezer to refrig- } \\
\text { erator in order to treat } \\
\text { the next day } \\
\text { GHP-GMP }\end{array}$ & $\begin{array}{l}\text { Microbiological } \\
\text { Increase of pathogens } \\
\text { Formation of toxins from } \\
\text { microorganisms } \\
\text { Cross-contamination from } \\
\text { staff } \\
\underline{\text { Chemical }} \\
\text { Chemicals from cleaning } \\
\text { materials } \\
\underline{\text { Physical }} \\
\text { Absence of impurities }\end{array}$ & $\begin{array}{l}\text { Temperature control / time } \\
2-4 \text { or } 6 \text { days for refrigerator } \\
0-3^{\circ} \mathrm{C} \\
\text { Calibration of the storage areas } \\
\text { Contractors specification of the } \\
\text { storage areas } \\
\text { Refrigerator insulation } \\
\text { FIFO } \\
\text { Implementation of standard } \\
\text { cleaning programs } \\
\text { Implementation of maintenance } \\
\text { programs } \\
\text { Avoiding cross-contamination } \\
\text { from other stock meat }\end{array}$ & & $\begin{array}{l}\text { Continuous temperature } \\
\text { control every } 15 \text { minutes } \\
\text { Preventive maintenance } \\
\text { program } \\
\text { Calibration } \\
\text { Control and check of resis- } \\
\text { tance time of the meat } \\
\text { Internal audits } \\
\text { Implementation of standard } \\
\text { cleaning programs } \\
\text { Plastic boxes must be clear } \\
\text { and clean } \\
\text { Continuous checks to iden- } \\
\text { tify improper meat }\end{array}$ \\
\hline $\begin{array}{l}\text { Preparation } \\
\text { (Transportation of raw } \\
\text { meat in the production } \\
\text { area for sorting and } \\
\text { entiph-s) }\end{array}$ & $\begin{array}{l}\text { Microbiological } \\
\text { Increase of pathogens } \\
\text { Viruses } \\
\text { Cross-contamination from } \\
\text { staff } \\
\text { Chemical } \\
\text { Chemicals from cleaning } \\
\text { materials } \\
\text { Physical } \\
\text { Absence of impurities (like } \\
\text { pieces of packaging materi- } \\
\text { als or equipment) }\end{array}$ & $\begin{array}{l}\text { Personal Hygiene - health } \\
\text { certificates } \\
\text { Immediate removal of waste } \\
\text { Swab test of the working sur- } \\
\text { face } \\
\text { Implementation of standard } \\
\text { cleaning programs } \\
\text { Continuous sterilization of the } \\
\text { working cutting knives }\left(83^{\circ} \mathrm{C}-\right. \\
45 \text { min). Change knives every } \\
30 \text { min }\end{array}$ & & $\begin{array}{l}\text { Internal audits } \\
\text { Calibration of the steriliza- } \\
\text { tion machine } \\
\text { Control and check of resis- } \\
\text { tance time of the meat }\end{array}$ \\
\hline
\end{tabular}


(Table 6). Contd.....

\begin{tabular}{|c|c|c|c|c|}
\hline $\begin{array}{l}\text { Step of the flow chat } \\
\text { (Fig.1) }\end{array}$ & Hazards & $\begin{array}{l}\text { Critical Factor/Limits/ } \\
\text { Controls }\end{array}$ & $\begin{array}{l}\text { Parameters to be moni- } \\
\text { tored for a particular CCP }\end{array}$ & Preventive measure \\
\hline $\begin{array}{l}\text { Preparation of solu- } \\
\text { tions (using water, } \\
\text { flavor enhancers, } \\
\text { preservatives) } \\
\text { CCP } 2 \text { (C) }\end{array}$ & $\begin{array}{l}\text { Microbiological } \\
\text { Cross-contamination from } \\
\text { the staff, water, and working } \\
\text { environment. } \\
\text { Increasing of pathogens } \\
\text { Viruses } \\
\text { Chemical } \\
\text { Chemicals from cleaning } \\
\text { materials } \\
\text { Physical } \\
\text { Absence of impurities }\end{array}$ & $\begin{array}{l}\text { Temperature control of the brine } \\
\left(0-4{ }^{\circ} \mathrm{C} \text { for } 12-24 \mathrm{~h}\right) \\
\text { Preparation of the brine accord- } \\
\text { ing to the recipe. All the quanti- } \\
\text { ties of the additives must be } \\
\text { according to the legislation and } \\
\text { directives (salts, nitrates, color- } \\
\text { ing, etc.) } \\
\text { Personal Hygiene - health cer- } \\
\text { tificates } \\
\text { Implementation of standard } \\
\text { cleaning programs in the prepa- } \\
\text { ration area } \\
\text { Microbiological analysis of } \\
\text { water } \\
\text { Balance calibrations }\end{array}$ & $\begin{array}{l}\text { Chemical parameters of the } \\
\text { recipes }\end{array}$ & $\begin{array}{l}\text { Internal audits } \\
\text { Calibration of the steriliza- } \\
\text { tion machine } \\
\text { Monitoring of the hygiene } \\
\text { of the employees } \\
\text { Monitoring of temperature } \\
\text { and time of the brine ( } 0-4 \\
\left.{ }^{\circ} \mathrm{C}, 12-24 \mathrm{~h}\right) \\
\text { Monitoring of correct reci- } \\
\text { pes } \\
\text { Monitoring of waste produc- } \\
\text { tion from the production } \\
\text { area } \\
\text { Monitoring of cleanliness of } \\
\text { equipment } \\
\text { Disinfection of equipment }\end{array}$ \\
\hline $\begin{array}{l}\text { Injection of the solu- } \\
\text { tions (in the cut meat } \\
\text { and in the milling and } \\
\text { mixing in case of } \\
\text { mincemeat) } \\
\text { GHP-GMP }\end{array}$ & $\begin{array}{l}\text { Microbiological } \\
\text { Cross-contamination from } \\
\text { staff, water, and working } \\
\text { environment } \\
\text { Increase of pathogens due to } \\
\text { the fact that the product is } \\
\text { exposed to the working } \\
\text { environment and the condi- } \\
\text { tions favor the increase of } \\
\text { microorganisms } \\
\text { Viruses } \\
\text { Chemical } \\
\text { Chemicals from cleaning } \\
\text { materials } \\
\text { Physical } \\
\text { Absence of impurities (like } \\
\text { pieces of packaging materi- } \\
\text { als or equipment or from } \\
\text { staff) }\end{array}$ & $\begin{array}{l}\text { Monitoring of the injection time } \\
\text { required for the uniform disper- } \\
\text { sion of the solution in the meat } \\
\text { mass (as the time of injection } \\
\text { increases the solution may affect } \\
\text { microbiological quality) } \\
\text { Health certificates of staff } \\
\text { Implementation of cleaning } \\
\text { programs } \\
\text { Implementation of maintenance } \\
\text { program in the injection } \\
\text { The uniform solution is filtered } \\
\text { before being recycled. The filter } \\
\text { must be cleaned } \\
\text { The small pieces of meat that } \\
\text { remain in the filter must be } \\
\text { removed immediately due to the } \\
\text { fact that may affect microbio- } \\
\text { logical quality }\end{array}$ & & $\begin{array}{l}\text { Internal audits } \\
\text { Monitoring of the hygiene } \\
\text { of the employees } \\
\text { Monitoring of injection } \\
\text { procedure } \\
\text { Monitoring of injection time } \\
\text { Implementation of cleaning } \\
\text { and disinfecting programs } \\
\text { Microbiological analysis of } \\
\text { the recycled solutions (the } \\
\text { parameters must be under } \\
\text { the limits of the raw meat) }\end{array}$ \\
\hline $\begin{array}{l}\text { Filling mixture into } \\
\text { forms } \\
\text { GHP-GMP }\end{array}$ & $\begin{array}{l}\text { Microbiological } \\
\text { Cross-contamination from } \\
\text { the staff, and working envi- } \\
\text { ronment. } \\
\text { Increasing of pathogens due } \\
\text { to the fact that the product is } \\
\text { exposed to the working } \\
\text { environment and the condi- } \\
\text { tions favored the increase of } \\
\text { microorganisms, microbial } \\
\text { load from the stainless steel } \\
\text { form or the plastic backs } \\
\text { Chemical } \\
\text { Chemicals from cleaning } \\
\text { materials and the plastic } \\
\text { forms } \\
\text { Physical } \\
\text { Absence of impurities (like } \\
\text { pieces of packaging materi- } \\
\text { als or equipment or from } \\
\text { staff) }\end{array}$ & $\begin{array}{l}\text { Monitoring of filling time of the } \\
\text { mixture } \\
\text { Health certificates of the staff } \\
\text { Implementation of cleaning } \\
\text { programs } \\
\text { Working instructions of the } \\
\text { filling procedures of the mixture } \\
\text { into forms } \\
\text { Migration test in the plastic } \\
\text { forms } \\
\text { Swab test in the forms }\end{array}$ & & $\begin{array}{l}\text { Supplier control and audits } \\
\text { Certificates for food grade } \\
\text { Migration analysis } \\
\text { Hygiene control } \\
\text { Implementation of cleaning } \\
\text { programs }\end{array}$ \\
\hline
\end{tabular}


(Table 6). Contd.....

\begin{tabular}{|c|c|c|c|c|}
\hline $\begin{array}{l}\text { Step of the flow chat } \\
\text { (Fig.1) }\end{array}$ & Hazards & $\begin{array}{l}\text { Critical Factor/Limits/ } \\
\text { Controls }\end{array}$ & $\begin{array}{l}\text { Parameters to be moni- } \\
\text { tored for a particular CCP }\end{array}$ & Preventive measure \\
\hline $\begin{array}{l}\text { Tumbler procedures. } \\
\text { Some products need to } \\
\text { be under cooling } \\
\text { conditions while con- } \\
\text { tinuously stirred } \\
\text { GHP-GMP }\end{array}$ & $\begin{array}{l}\text { Microbiological } \\
\text { Cross-contamination from } \\
\text { staff and working environ- } \\
\text { ment. } \\
\text { Chemical } \\
\text { Chemicals from cleaning } \\
\text { materials and plastic forms } \\
\text { Physical } \\
\text { Absence of impurities (like } \\
\text { pieces of packaging materi- } \\
\text { als or equipment or from } \\
\text { staff) }\end{array}$ & $\begin{array}{l}\text { Freezing speed and mixing time } \\
\text { (freezing must be achieved } \\
\text { quickly in order to avoid the } \\
\text { possibility of the increasing } \\
\text { temperature) } \\
\text { Implementation of cleaning } \\
\text { programs } \\
\text { Personal hygiene } \\
\text { Implementation of maintenance } \\
\text { programs }\end{array}$ & & $\begin{array}{l}\text { Hygiene control } \\
\text { Implementation of cleaning } \\
\text { programs and disinfections } \\
\text { Monitoring of the freezing } \\
\text { speed } \\
\text { Temperature must be be- } \\
\text { tween }-3 \text { and }+3^{\circ} \mathrm{C} \\
\text { Monitoring of stirring } \\
\text { Monitoring of pressure into } \\
\text { the tumbler } \\
\text { Calibration (temperature, } \\
\text { speed and pressure) }\end{array}$ \\
\hline $\begin{array}{l}\text { Residence / Storage } \\
\text { under cooling condi- } \\
\text { tions } \\
\text { CCP3 (M) }\end{array}$ & $\begin{array}{l}\text { Microbiological } \\
\text { Cross-contamination from } \\
\text { staff and the refrigerator } \\
\text { Chemical } \\
\text { Chemicals from cleaning } \\
\text { materials and plastic forms } \\
\text { Physical } \\
\text { Absence of impurities (from } \\
\text { equipment or staff) }\end{array}$ & $\begin{array}{l}\text { Monitoring of temperature } \\
\text { control } \\
\text { Personal hygiene } \\
\text { Implementation of maintenance } \\
\text { program of the refrigerator } \\
\text { Implementation of cleaning } \\
\text { program } \\
\text { Swab test on the surface of the } \\
\text { refrigerator } \\
\text { FIFO }\end{array}$ & Temperature & $\begin{array}{l}\text { Monitoring of temperature } \\
\text { and time of the product in } \\
\text { the refrigerator } \\
\text { Calibration (temperature) } \\
\text { Monitoring of maintenance } \\
\text { and cleaning programs } \\
\text { Internal Audits } \\
\text { Hygiene control }\end{array}$ \\
\hline $\begin{array}{l}\text { Preparation for Cook- } \\
\text { ing (Filling mixture } \\
\text { into forms, suspension } \\
\text { / hanging of ready } \\
\text { meat in trackless } \\
\text { trolley) } \\
\text { GHP-GMP }\end{array}$ & $\begin{array}{l}\text { Microbiological } \\
\text { Cross-contamination from } \\
\text { staff, increase of pathogens, } \\
\text { formation of toxins } \\
\text { Chemical } \\
\text { Chemicals from cleaning } \\
\text { materials and plastic forms. } \\
\text { Physical } \\
\text { Absence of impurities (from } \\
\text { equipment or staff) }\end{array}$ & $\begin{array}{l}\text { Monitoring of temperature and } \\
\text { time of meat (minimum hanging } \\
\text { time in order to avoid cross- } \\
\text { contamination) } \\
\text { Personal hygiene } \\
\text { Implementation of cleaning } \\
\text { program } \\
\text { Swab test in the surface of the } \\
\text { hook }\end{array}$ & & $\begin{array}{l}\text { Hygiene control } \\
\text { Implementation of cleaning } \\
\text { programs and disinfections } \\
\text { of all stainless steel and } \\
\text { especially the hook } \\
\text { Working instructions. Avoid } \\
\text { doing anything else near the } \\
\text { hook }\end{array}$ \\
\hline $\begin{array}{l}\text { Addition of other } \\
\text { ingredients (surface } \\
\text { aromatics) } \\
\text { GHP-GMP }\end{array}$ & $\begin{array}{l}\text { Microbiological } \\
\text { Salmonella spp, Bacillus } \\
\text { cereus, Clostridium botu- } \\
\text { linum, Staphylococcus } \\
\text { aureus, E. coli, Faecal coli- } \\
\text { forms, Clostridium perfrin- } \\
\text { gens, Coliforms, Enterobac- } \\
\text { teria } \\
\underline{\text { Chemical }} \\
\text { Toxins (aflatoxins) } \\
\text { Physical } \\
\text { Absence of impurities }\end{array}$ & $\begin{array}{l}\text { Products specifications } \\
\text { Shelf life } \\
\text { TVC }: 5 \times 10^{5} \\
\text { Salmonella spp: } 0 / 25 \mathrm{~g} \\
\text { E. coli: negative }-2 \times 10^{2} \\
\text { Staphylococcus aureus: } 1 \times 10^{2} \\
\text { Clostridium perfringens: } 1 \times 10^{2} \\
\text { Coliforms or Enterobacteria: } \\
5 \times 10^{2} \\
\text { Toxins }\end{array}$ & & $\begin{array}{l}\text { Supplier control and audits } \\
\text { Transformation control and } \\
\text { checks (hygiene checks) } \\
\text { Temperature control } \\
\text { Organoleptic characteristics } \\
\text { (color, smell, appearance) } \\
\text { Microbiological analysis } \\
\text { Personal hygiene } \\
\text { Health certificates } \\
\text { Free from aflatoxins }\end{array}$ \\
\hline $\begin{array}{l}\text { Thermal Process } \\
\text { (Cooking: including } \\
\text { drying, boiling and } \\
\text { smoking) } \\
\text { CCP4 (M) }\end{array}$ & $\begin{array}{l}\text { Microbiological } \\
\text { Elimination of all pathogens } \\
\text { (present in raw meat or } \\
\text { having increased during } \\
\text { previous steps) in safe levels } \\
\text { for the consumer } \\
\text { Chemical } \\
\text { From cleaning materials } \\
\text { Physical } \\
\text { Absence of impurities (like } \\
\text { parts of equipment from the } \\
\text { oven) }\end{array}$ & $\begin{array}{l}\text { Monitoring of temperature }(\mathrm{T} \geq \\
\left.73^{\circ} \mathrm{C}\right) \\
\text { Monitoring of time } \\
\text { Implementation of cleaning } \\
\text { program } \\
\text { Monitoring of maintenance } \\
\text { program } \\
\text { Calibration }\end{array}$ & $\begin{array}{l}\text { Temperature } \\
\text { Calibration }\end{array}$ & $\begin{array}{l}\text { Monitoring temperature and } \\
\text { time of thermal process } \\
\text { Monitoring maintenance } \\
\text { and cleaning programs } \\
\text { Monitoring product tem- } \\
\text { perature inside the oven } \\
\text { Implementation of oven } \\
\text { cleaning program } \\
\text { Monitoring of air filtration }\end{array}$ \\
\hline
\end{tabular}


(Table 6). Contd.....

\begin{tabular}{|c|c|c|c|c|}
\hline $\begin{array}{l}\text { Step of the flow chat } \\
\text { (Fig.1) }\end{array}$ & Hazards & $\begin{array}{l}\text { Critical Factor/Limits/ } \\
\text { Controls }\end{array}$ & $\begin{array}{l}\text { Parameters to be moni- } \\
\text { tored for a particular } \mathrm{CCP}\end{array}$ & Preventive measure \\
\hline $\begin{array}{l}\text { Exit from the Oven - } \\
\text { Entry in a Chiller or } \\
\text { Refrigerator CCP5 } \\
\text { (M) }\end{array}$ & $\begin{array}{l}\text { Microbiological } \\
\text { Cross-contamination from } \\
\text { staff and the chiller, increas- } \\
\text { ing of pathogens, formation } \\
\text { of toxins } \\
\text { Chemical } \\
\text { From cleaning materials } \\
\text { Physical } \\
\begin{array}{l}\text { Absence of impurities (from } \\
\text { equipment or staff) }\end{array}\end{array}$ & $\begin{array}{l}\text { Monitoring of temperature < } \\
4^{\circ} \mathrm{C} \\
\text { Personal hygiene } \\
\text { Implementation of cleaning } \\
\text { program } \\
\text { Avoid unnecessary movement } \\
\text { in the chiller }\end{array}$ & Temperature & $\begin{array}{l}\text { Monitoring maintenance } \\
\text { and cleaning programs } \\
\text { Calibration } \\
\text { Personal hygiene } \\
\text { Internal audits } \\
\text { Note: The products are in } \\
\text { the final step ready to be } \\
\text { sold and should not be } \\
\text { cross-contaminated. There is } \\
\text { no other step to confront any } \\
\text { hazard. }\end{array}$ \\
\hline $\begin{array}{l}\text { Packaging (cutting } \\
\text { and packaging) } \\
\text { CCP6 }(\mathrm{M}, \mathrm{P})\end{array}$ & $\begin{array}{l}\text { Microbiological } \\
\text { Cross-contamination from } \\
\text { packaging materials, cutting } \\
\text { machines } \\
\text { Chemical } \\
\text { From cleaning materials, } \\
\text { residual disinfectants } \\
\text { Physical } \\
\text { Typical, like equipment } \\
\text { from the cutting machine, } \\
\text { pieces from packaging ma- } \\
\text { terials }\end{array}$ & $\begin{array}{l}\text { Product specifications } \\
\text { Food grade certificates of pack- } \\
\text { aging materials } \\
\text { Migration test } \\
\text { Batch numbers } \\
\text { Monitoring of hygiene program } \\
\text { Swab test } \\
\text { Calibration of balance } \\
\text { Personal hygiene } \\
\text { Implementation of maintenance } \\
\text { program } \\
\text { Metal detector should be } \\
\text { checked }\end{array}$ & $\begin{array}{l}\text { Migration test } \\
\text { Swab test on the cutting } \\
\text { machine, on packaging } \\
\text { materials, on the employees' } \\
\text { hands (TVC }<10 / 10 \mathrm{~cm}^{2} \text { ) } \\
\text { Monitoring of metal detector }\end{array}$ & $\begin{array}{l}\text { Supplier control and audits } \\
\text { Certificates for food grade } \\
\text { Hygiene control } \\
\text { Monitoring the vacuum } \\
\text { machine } \\
\text { Calibration of pressure } \\
\text { Monitoring of batch num- } \\
\text { bers } \\
\text { Internal audits } \\
\text { Monitoring personal hy- } \\
\text { giene } \\
\text { Note: Personal hygiene is } \\
\text { very important due to the } \\
\text { fact that if the product is } \\
\text { contaminated there is no } \\
\text { other step to encounter the } \\
\text { hazard. }\end{array}$ \\
\hline $\begin{array}{l}\text { Storage of the vacuum } \\
\text { packaged products } \\
\text { CCP7 (M) }\end{array}$ & $\begin{array}{l}\text { Microbiological } \\
\text { Salmonella spp, Campy- } \\
\text { lobacter, Staphylococcus } \\
\text { aureus, Clostridium perfrin- } \\
\text { gens, Clostridium botu- } \\
\text { linum, Escherichia coli, } \\
\text { Yersinia enterocolitica, } \\
\text { Listeria monocytogenes, E. } \\
\text { coli and Faecal coliforms, } \\
\text { Coliforms or Enterobacteria. } \\
\text { Chemical } \\
\begin{array}{l}\text { Additives, nitrates, gluta- } \\
\text { mate }\end{array} \\
\text { Physical } \\
\text { Absence of impurities }\end{array}$ & $\begin{array}{l}\text { Monitoring of storage tempera- } \\
\text { ture }\left(0-4^{\circ} \mathrm{C}\right) \text { or }\left(-18^{\circ} \mathrm{C}\right) \\
\text { Product specifications } \\
\text { Microbiological characteristics: } \\
\text { TVC (aerobic) }: 10^{5} \\
\text { TVC (anaerobic) }: 10^{5} \\
\text { E. coli and Faecal coliforms: } \\
0 / \mathrm{g}-1 \times 10^{2} \\
\text { Coliforms or Enterobacteria: } \\
5 \times 10^{3} \\
\text { Salmonella spp: } 0 / 25 \mathrm{~g} \\
\text { Staphylococcus aureus: } 0 / \mathrm{g}- \\
5 \times 10^{2} \\
\text { Clostridium perfringens:0//0.1g } \\
\text { Campylobacter and Yersinia: } \\
0 / 25 \mathrm{~g} \\
\text { Chemical characteristics: addi- } \\
\text { tives, nitrates, etc. according to } \\
\text { legislation and directives } \\
\text { Monitoring of products' shelf } \\
\text { life } \\
\text { Pest control } \\
\text { Implementation of cleaning } \\
\text { program } \\
\text { FIFO }\end{array}$ & $\begin{array}{l}\text { Temperature }\left(0-4^{\circ} \mathrm{C}\right) \text { or } \\
\left(-18^{\circ} \mathrm{C}\right) \\
\text { Microbiological analysis in } \\
\text { the final product }\end{array}$ & $\begin{array}{l}\text { Internal audits } \\
\text { Monitoring of hygiene pro- } \\
\text { gram } \\
\text { Monitoring shelf life of } \\
\text { products }\end{array}$ \\
\hline $\begin{array}{l}\text { Product distribution } \\
\text { GHP-GMP }\end{array}$ & $\begin{array}{l}\text { Microbiological } \\
\text { Salmonella spp, Campy- } \\
\text { lobacter, Staphylococcus } \\
\text { aureus, Clostridium perfrin- } \\
\text { gens, Clostridium botu- } \\
\text { linum, Escherichia coli, } \\
\text { Yersinia enterocolitica, } \\
\text { Listeria monocytogenes, E. } \\
\text { coli and Faecal coliforms, } \\
\text { Coliforms or Enterobacteria. } \\
\text { Chemical } \\
\text { Cross-contamination from } \\
\text { transportation }\end{array}$ & $\begin{array}{l}\text { Monitoring of storage tempera- } \\
\text { ture }\left(0-4^{\circ} \mathrm{C}\right) \text { or }\left(-18^{\circ} \mathrm{C}\right) \text {, moisture } \\
85-90 \% \\
\text { Product specifications }\end{array}$ & & $\begin{array}{l}\text { Monitoring temperature } \\
\text { Calibration } \\
\text { Internal audits } \\
\text { Monitoring of hygiene pro- } \\
\text { gram } \\
\text { Implementation of mainte- } \\
\text { nance program } \\
\text { Microbiological analysis }\end{array}$ \\
\hline
\end{tabular}


Table 7. General GHPs-GMPs Per Step

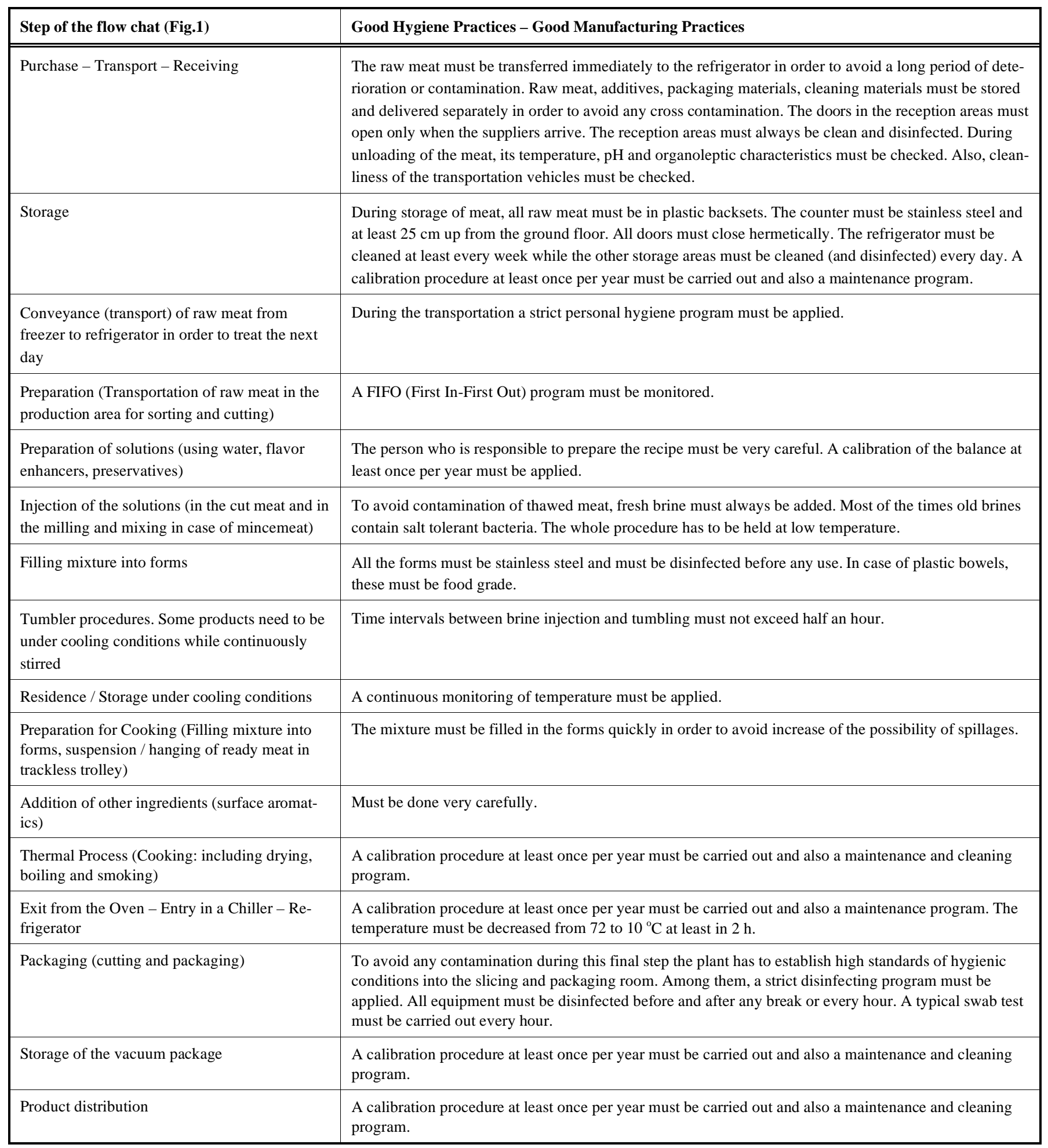

equipment and the environment plant. It is obvious that good hygiene practices are a useful prerequisite tool for an efficient HACCP system. Moreover, it is necessary for all products to avoid moving back and forth to minimize possible cross-contamination and their movement from one step of the processing line to another has to be done quickly with no delay.

\section{CONCLUSIONS}

The detailed analysis of the safety and hygiene factors affecting the quality and safety the whole processing of the examined meat delicatessen products (bacon, lountza, hiromeri, ham, sausages) proved that the control of CCPs relative to raw materials' specifications or temperatures in retaining or thermal processing steps, as well as the PRPs rela- 
tive to the hygienic conditions during production should be satisfied.

\section{REFERENCES}

[1] Codex Alimentarius CAC/RCP 1. Recommended International Code of Practice. General Principles of Food Hygiene. CAC/RCP 1-1969, Rev. 3-1997, Amd. 1999.

[2] Codex Alimentarius Commissions. Proposed draft principles and guidelines for the conduct of microbiological risk management (at step 3 of the procedure). CX/FH 03/7. Joint FAO/WHO Food Standards Programme 2002.

[3] Tzia C, Tsiapouris A. Application of the hazard analysis critical control point (HACCP) system in the food industry. Athens: Papasotiriou (in Greek) 1996; pp. 17-32.

[4] ISO 22000. International Standard. Food safety management system. Requirement for any organization in the food chain. 2005

[5] Christaki T, Tzia C. Quality and safety assurance in winemaking. Food Control 2003; 13: 503-17.

[6] Notermans S, Zwietering M, Mead G. The HACCP concept: identification of potentially hazardous micro-organism. Food Microbiol 1994; 11; 203-14.

[7] Panisello P, Rooney R, Quantick PC, Stanwell-Smith R. (). Application of foodborne disease outbreak data in the development and maintenance of HACCP systems. Int J Food Microbiol 2000; 59: 221-34.

[8] Serra JA, Domenech E, Escrishe I, Martorell S. Risk assessment and critical control points from the production perspective. Int $\mathbf{J}$ Food Microbiol 1999; 46: 9-26.

[9] Todd ECD, Guzewich JJ, Bryan FL. Surveillance of foodborne disease IV. Dissemination and uses of surveillance data. J Food Prot 1997; 60: 715-23.

[10] Ropkins K, Beck AJ. Evaluation of worldwide approaches to the use of HACCP to control food safety. Trends Food Sci Technol 2000; 11: 10-21.

[11] Council Directive 93/43/EEC of 14 June 1993 on the hygiene of foodstuffs. 1993.

[12] Regulation (EC) No 852/2004 of the European Parliament and of the Council of 29 April 2004 on the hygiene of foodstuffs. 2004.
[13] Regulation (EC) No 178/2002 of the European Parliament and of the Council of 28 January 2002 laying down the general principles and requirements of food law, establishing the European Food Safety Authority and laying down procedures in matters of food safety. 2002.

[14] Commission Regulation (EC) No 853/2002 of 22 May 2002 fixing the import duties in the rice sector. 2002.

[15] Regulation (EC) No 854/2004 of the European Parliament and of the Council of 29 April 2004 laying down specific rules for the organization of official controls on products of animal origin intended for human consumption. 2004.

[16] Conter M, Zanardi E, Ghidini S, et al. Survey on typology, PRPs and HACCP plan in dry fermented sausage sector of Northern Italy. Food Control 2007; 18: 650-5.

[17] Panisello PJ, Quantick PC. Technical barriers to hazard analysis critical control point (HACCP). Food Control 2002; 12: 165-73.

[18] Taylor E. HACCP in small companies: benefit or burden? Food Control 2001; 12: 217-22.

[19] Taylor E, Kane K. Reducing the burden of HACCP on SMEs. Food Control 2005; 16: 833-39.

[20] Walker E, Pritchard C, Forsythe S. Hazard analysis critical control point and prerequisite program implementation in small and medium size food business. Food Control 2003; 14: 169-74.

[21] Metaxopoulos J, Kritikos D, Drosinos EH. Examination of microbiological parameters relevant to the implementation of GHP and HACCP system in Greek meat industry in the production of cooked sausages and cooked cured meat products. Food Control 14: 32332.

[22] Grill CO, \& Molin G. Modified atmosphere and vacuum packaging. In: Russell NJ, Gould GW, Eds. Food preservatives. Glasgow: Blackie 1991; pp. 172-199.

[23] Council Directive 98/83/EC of 3 November 1998 on the quality of water intended for human consumption.1998.

[24] Directive 2000/60/EC of the European Parliament and of the Council of 23 October 2000 establishing a framework for Community action in the field of water policy. 2000.

(C) Zorpas et al.; Licensee Bentham Open.

This is an open access article licensed under the terms of the Creative Commons Attribution Non-Commercial License (http://creativecommons.org/licenses/by-nc/3.0/) which permits unrestricted, non-commercial use, distribution and reproduction in any medium, provided the work is properly cited. 